\title{
Unconstitutional Conditions: Welfare Benefits with Strings Attached
}

\author{
Robert M. O'Neil**
}

$\mathbf{M}$

AX A STATE COMPEL a foreign corporation, in order to transact business within the state, to forego removal of lawsuits to the federal courts? ${ }^{1}$ May the same state require recipients of welfare benefits to agree not to join certain political organizations while they receive benefits? Surprisingly, constitutional law has tended to view these two questions as almost equivalent. Both, it has been said, raise problems of unconstitutional conditions.

The vital differences between these two cases should be rather obvious. Both the corporation and the welfare-seeker face, to be sure, a superficially similar choice: whether to accept the benefit encumbered by the condition, or forego the benefit because of reluctance to submit to the condition. But that theoretical if beguiling similarity obscures critical differences whicli warrant different legal analysis. The choice facing the corporate management calls for an essentially practical, economic decisionis it worth relinquishing the opportunity to remove cases to the federal courts in order to carry on local business? If the price is excessive, many other markets beckon. Even if the state which imposes the offensive condition happens to be the site of the principal or most logical market, the corporation may avoid the condition by incorporating there. Thus the decision whether to accept or reject the condition in order to obtain the benefit is an unemotional, objective one. ${ }^{2}$

* A.B., 1956, A.M., 1957, LL.B., 1961, Harvard University; Acting Associate Professor of Law, University of California (Berkeley).

1 The case on which the question is based is Doyle v. Continental Ins. Co., 94 U.S. 535 (1877). The Court's holding that such a condition could constitutionally be imposed was overruled in Terral v. Burke Constr. Co., 257 U.S. 529 (1922). See generally Willcox, Invasions of the First Amendment Through Conditioned Public Spending, 41 CORNELI L.Q. $12,22-23$ (1955).

2 This is not to say, of course, that the corporate decision may not be a difficult and even painful one for those charged with making it. In a time of greater solicitude for the foreign corporation than the present, the Supreme Court held that California could not constitutionally compel a contract carrier seeking to do business within the state to assume the burdens of a common carrier as a condition of the "privilege" of using the state's highways. Mr. Justice Sutherland spoke feelingly of the dilemma facing the corporation confronted with such an unpalatable option: "In reality, the carrier is given no choice, except a choice between the rock and the whirlpool, -an option to forego a privilege which may be vital to his livelihood or submit to a requirement which may constitute an intolerable burden." Frost \& Frost Trucking Co. v. Railroad Comm'n, 271 U.S. 583, 593 (1926). For the Court's lack of corresponding solicitude for the dilemma of individuals seeking conditioned benefits, see, e.g., Elamilton v. Regents of the Univ. of Calif., 293 U.S. 245 (1934). 
The dilemma of the indigent welfare-seeker contrasts sharply. In the first place, the very fact of asking for public assistance imposes an unavoidable stigma. Second, the consequence of refusing the benefit is quite different: An indigent person's ability to survive without public assistance is hardly comparable to the ambitious corporation's quest for new markets. $^{3}$ Third, the effects of comphance with the condition are usually quite different: A compelled loyalty oath, for example, may subtly coerce avoidance not only of "disloyal" groups but of all controversial political affiliation, ${ }^{4}$ while the inability to remove corporate suits to the federal courts seems unlikely to carry profound collateral consequences.

Thus the cases of the welfare-seeker and the interstate business seem so fundamentally different that constitutional scholars and courts should long ago have stopped trying to fit them to the same mold. This article will suggest some principles of constitutional analysis more germane to the problems of welfare benefits than those that have been developed in the corporate context. A fresh look of this sort is already overdue. The need for a thorough reexamination is heightened by the expansion of government welfare and other benefit programs. The conditioning of benefits, indeed, is one of the pressing constitutional problems confronting lawyers in the welfare state.

TYPES OF CONDITIONED BENEFITS

The initial task is to identify the various forms of benefits which have been conditioned by government programs of spending. This is a necessary first step before considering the more important matters of types of conditions and reasons for imposing them.

Before classifying benefits, however, we must inquire whether there are any opportumities afforded by government to its citizens which are constitutionally exempt from encumbrances. Freedom of speech, for example, is clearly a "right" of the highest priority. One may not be compelled to pay for the opportunity to speak, ${ }^{5}$ nor required to submit to previous censorship. ${ }^{b}$ But a speaker may be compelled to register with local authorities or obtain a minimal permit before he speaks, so long as no infringement of his message is involved. The other government

\footnotetext{
3 See generally, for a sympathetic view of the problems confronting the welfarc-seeker, Reicb, Individual Rights and Social Welfare: the Emerging Legal Issues, 74 YaLE L.J. 1245-46 (1965),

${ }^{4}$ See note 30 infra and accompanying text.

5 Murdock v. Pennsylvania, 319 U.S. 105 (1943).

6 Cantwell v. Connecticut, 310 U.S. 296 (1940).

7 Compare Poulos v. New Hampshire, 345 U.S. 395 (1953), with Thomas v. Collins, 323 U.S. 516 (1945).
} 
benefit which seems most clearly a "right" is the franchise. It might be thought that voting is so essential to a democracy that no conditions could be imposed upon the franchise. Recently, however, it has taken a constitutional amendment ${ }^{8}$ and a major Supreme Court decision to abolish the last vestiges of the poll tax..$^{9}$ Even the most recent federal legislation protecting the franchise seems to assume the validity of some conditions and qualifications upon its exercise. ${ }^{10}$ Thus it appears that few if any forms of government benefit are so essential or of such a high order that they cannot constitutionally be conditioned in any way.

The most inviting distinction in the field of government benefits is the one that has been drawn between "rights" and "privileges." Those who start with this distinction then conclude that a "privilege," being a mere government gratuity, can be conditioned without limit because it could be withdrawn without notice or formal proceeding." "Rights," on the other hand, have to be treated circumspectly because they are in some sense "vested," and cannot be summarily withdrawn or arbitrarily denied. The distinction is circular as well as illusory. Recent scholarship has shown low flimsy it is, and has urged that it slould be abandoned, ${ }^{12}$ although there are courts which cling to the security it affords in analyzing government benefits. ${ }^{13}$

To break out of the right-privilege circle, it would be more useful to

8 U.S. CoNST. amend. XXIV.

9 Harper v. Virginia State Board of Elections, 86 S. Ct. 1079 (1966).

10 Only certain types of literacy tests are prohibited by the Civil Rights Act of 1964, 78 Stat. 24I, 42 U.S.C. $\$ 1971$ (a) (2) (C) (1964), or suspended by the Voting Rights Act of 1965, 79 Stat. 437, 42 U.S.C. $\$ \S 1973-73$ p (Supp. I, 1965). Where such tests are administered in writing and are not used for racially discriminatory purposes, they may still be permitted.

11 The most durable statement of the "privilege" concept, if not the soundest, was Justice Holnes' epigran in the case involving a municipal ban on the political activities of city employees: "The petitioner may have a constitutional right to talk politics, but he has no constitutional right to be a policeman." McAuliffe v. Mayor \& Board of Aldermen, 155 Mass. 216, 220, 29 N.E. 517 (1892). In a similar vein is Professor Hale's classic statement: "[The] doctrine of unconstitutional conditions . . . is difficult to support logically. If I have no ground for complaint at being denied a privilege absolutely, it is difficult to see how I acquire such a ground nerely because the state, instead of denying me a privilege outright, offers me an alternative, however harsh." Hale, Unconstitutional Conditions and Constitutional Rights, 35 CoLUs. L. REv. 32I-22 (1935).

12 See, e.g., French, Comment: Unconstitutional Conditions: An Analysis, 50 GEo. L.J. 234, 236-39 (1961).

13 Probably the last clear adherence to the "privilege" concept in Suprene Court jurisprudence was Adler v. Board of Educ., 342 U.S. 485, 492 (1952). Although the Court has never squarely repudiated the doctrine, recent decisions have conveniently avoided consideration of the right-privilege distinction. E.g., Sherbert v. Verner, 374 U.S. 398 (1963). But lower courts occasionally take solace in the distinction. See, e.g., Thonpson v. Gleason, 317 F.2d 901, 906 (D.C. Cir. 1962). For a summary of the development, see Linde, Justice Douglas on Freedom in the Welfare State: Constitutional Rights in the Publif Sector, 39 WASE. L. REv. 4, 31-32 (1964). 
speak of a single category of "benefits." This category runs the gamut from the most securely protected activities sanctioned or underwritten by government (such as the practice of the basic professions under government license), to the most ephemeral government gratuities (bonus payment or rewards for valor, for example). Thus no distinction need be drawn at any arbitrary point between "rights" and "privileges"; it need only be recognized that in terms of the interests both of the donor and of the recipient, some forms of government benefits are more valuable than others, and should be more fully safeguarded. ${ }^{14}$ But the withdrawal or conditionimg of all types of benefits should be analyzed according to the same constitutional principles.

A complete catalogue of the kinds of government benefits now provided in the United States would serve no useful purpose; an illustrative survey should suffice here. Public employment: is usually seen as a distinct category-partly because employment is a very important kind of opportunity to the recipient, and partly because there are more cases dealing with the conditioning of employment than any other benefit. ${ }^{15}$ But employment is not really different in kind from other benefits, and the creation of a discrete category may therefore obscure the assimilation which is urged here.

Public education is another class of benefits sometimes singled out for special treatment. Elementary and secondary education has always been among the most vital opportunities afforded by government, and the courts liave been careful to protect the rights of students and parents. ${ }^{10}$ Also recent changes in the character of public higher education, from bare luxury to near necessity, have obviously altered its position on the hierarchy of benefits, ${ }^{17}$ and may have rendered obsolete most of the old cases about conditioning the privilege of attending a state university. ${ }^{18}$

14 This appears to have been the United States Supreme Court's disposition in recent cases. For example, in the process of deciding that a pohtical deportee forfeited all claims to social security, the Court nevertheless recognized that his claim to benefits "is of sufficient substance to fall within the protection from arbitrary governmental action afforded by the Due Process Clause." Flemming v. Nestor, 363 U.S. 603, 611 (1960). The need to draw such a distinction has been similarly avoided in other recent decisions involving the withdrawal or conditioning of government benefits, e.g., Schware v. Board of Bar Examiners, 353 U.S. 232, 239 n.5 (1957); Wieman v. Updegraff, 344 U.S. 183, 192 (1952).

15 For an extended discussion of the special problems of conditioned access to pubhic employment, see Linde, supra note 13, at 31-46.

16 See, e.g., Comment, 37 U. CoLo. L. REv. 492 (1965); note 57 infra.

17 See Van Alstyne, Student Academic Freedom and the Rule-Making Powers of Public Universities: Some Constitutional Considerations, 2 Law IN Transirion Q. 1, 6-8 (1965).

18 Compare, e.g., Hamilton v. University of Cahif. Board of Regents, 293 U.S. 245 (1934); North v. Board of Trustees, 137 IIl. 296, 27 N.E. 54 (1891), with the more recent pronouncements in, e.g., Dixon v. Alabama State Board of Educ., 294 F.2d 150 (5th Cir. 1961); Connelly v. University of Vt., 244 F. Supp. 156 (D. Vt. 1965); Knight v. Board of Educ., 
Many government benefits come in the form of licenses or permits. Running the gamut from admission to the basic professions to weekend fishing licenses, benefits of this sort are among the most important that government can offer to the citizen. Nowhere has the classic right-privilege distinction proved more pernicious. Yet nowhere is it more apparent that some types of conditions are not only legitimate but essential. For example, few would question the wisdom of ascertaining a doctor's or lawyer's professional skills before turning him loose upon a trusting public. Having said that does not, lowever, always determine where to draw the line between legitimate tests of professional qualification and illegitimate tests of unrelated personal characteristics. Mr. Justice Douglas has argued that "nothing in a man's political beliefs disables lim from setting broken bones or removing ruptured appendixes safely and efficiently"; 19 but the cases that now trouble the courts tend to be subtler than the one about which Douglas was speaking.

It would be easy, but misleading, to overlook the category of government benefits comprised of opportunities to use various public facilities. While we tend to take for granted access to public parks and playgrounds, there has been much controversy over such less obvious benefits as the use of the mails ${ }^{20}$ and of higl school auditoriums for public meetings. ${ }^{21}$ When one considers the wliole range of public facilities that have been made available to the citizen, and to citizen groups, for essentially nongovermmental activities, the siguificance of this class of government benefits becomes apparent.

Finally, there are the myriad governmental benefits that have characterized the development of the welfare state. Most of these benefits are designed to remedy or offset the effects of unequal distribution of resources in the private sector or to cushion the impact of illness or other misfortunes-unemployment compensation, workmen's compensation,

200 F. Supp. 174 (M.D. Tenn. 1961); Manjares v. Newton, 64 A.C. 378, 411 P.2d 901, 49 Cal. Rptr. 805 (1966).

19 Barsky v. Board of Regents, 347 U.S. 442, 474 (1954) (Douglas, J., dissenting). The questions of relevance of qualifications and conditions to the purposes of the benefit program, and of the relationship between the condition and the alleged purpose, will be considered more fully in the text accompanying notes 97-102 infra.

20 Compare Milwaukee Social Democratic Publishing Co. v. Burleson, 255 U.S. 407 (1921), with Lamont v. Postmaster General, 381 U.S. 301 (1965) ; Hannegan v. Esquire, Inc., 327 U.S. 146 (1946) ; United States v. 18 Packages of Magazines, 238 F. Supp. 846 (N.D. Cal. 1964).

${ }^{21}$ See, e.g., Bynum v. Schiro, 219 F. Supp. 204 (E.D. La. 1963); American Civil Liberties Umion v. Board of Educ., 59 Cal. 2d 203, 379 P.2d 4, 28 Cal. Rptr. 700 (1963); American Civil Liberties Umion v. Board of Educ., 55 Cal. 2d 167, 359 P.2d 45, 10 Cal. Rptr. 647 (1961); Danskin v. San Diego Unified School Dist., 28 Cal. 2d 536, 171 P.2d 885 (1946); Blease, The Civic Center Act and the Freedom of Speech, 2 CaLrF. Comm's on Law \& Soctar Action L. Comamentarx 43 (1964). 
medical care payments, social security, college scholarships, rent subsidies, and the like, to mention but a few of the commoner forms of welfare payments. It is the conditioning of such benefits that poses the most serious constitutional problems today, for several reasons: first, because the "privilege" dogma has clung most assiduously to welfare benefits; second, because those affected by such conditions are less able to resist or to litigate the questions than those affected by conditions on other forms of benefits; and third, because conditions imposed on welfare benefits are likely to be most remote from the purposes or aims of the benefit program itself. It is these factors which serve to focus the principal attention of the present article upon conditioning of welfare benefits, though in so doing we must not shight problems of conditioned benefits of the other varieties previously discussed.

Before moving on, something should be said about the inherent limitations of any classification of benefits such as we have just set forth. The distinctions drawn in this section are of descriptive significance only. This brief survey has reflected none of the analytical distinctions that would be essential to the making of constitutional judgments about the legitimacy of conditions. There has been, for example, no attempt here to rank benefits in order of their value or importance either to the recipient or to the benefactor. Some attention will be given to such distinctions in a later section where functional differences figure more prominently. Here the object has been only to present a gross descriptive survey for its reference value.

\section{II}

TYPES OF CONDITIONS

It seems appropriate at the outset to survey the various types of conditions much as we have just surveyed the benefits. ${ }^{22}$ It should be stressed agaim that some conditions are not only legitimate but essential to any orderly system of government regulation. Medical licenses could hardly be issued, for example, without some demonstration of professional training and skill. And the appropriation of federal and state funds must constitutionally be accompanied by a stipulation, express or implied, that they not be spent for racially discriminatory purposes ${ }^{23}$ Conditions, then, may

22 No attempt will be made to illustrate all the types of conditions described in this section. Indeed, some of them may be hypothetical, although unintentionally. For a survey of some of the most onerous forms of conditions still found in welfare legislation, see Reich, supra note 3 , at 1246-51.

23 See, e.g., Smith v. Holiday Inns of America, Inc., 336 F.2d 630 (6th Cir. 1964); Simkins v. Moses H. Cone Memorial Hosp., 323 F.2d 959 (4th Cir. 1963). Today the constitutional obligation has been strongly reinforced by the statutory obligation of Title VI of the Civil Rights Act of 1964, 78 Stat. 252 (1964), 42 U.S.C. $\$ \$ 2000$ d-2000d-4 (1964). 
be benign and beneficial as well as malevolent and devious. The survey which we are about to undertake must, therefore, view the conditioning process with an objective and impartial eye.

There are many government benefit programs which are "conditioned" only to the extent that himits of monetary amount or duration are imposed upon the eligibility of a particular individual. Unemployment compensation may run out after twenty-six weeks, for example, or medical expenses may be reimbursable only up to 5,000 dollars. (Sometimes, of course, the beneficiary has a choice regarding the condition: he may purchase a hunting license for the entire season at twenty-five dollars, or a weekend permit for ten dollars.) Such conditions as these are unlikely to be used for ulterior purposes, even where the dispensing government seems unduly parsimonious. Nor do such limitations often deter constitutionally protected conduct.

More troublesome are various conditions imposed in the nature of qualifications. If professional skill is the requisite qualification for a license, questions may arise with respect to the manner of ascertaining the skill. Many benefits are restricted in terms of the qualification of residence or citizenship-state jobs may, for example, be open only to residents of the state, or relief rolls may be closed to persons who have newly migrated to the city or the county. ${ }^{24}$ These qualifications, although sometimes harsh; and arguably unconstitutional, should be clearly distinguished from other qualifications, such as race or ancestry, which rest upon a closed, fixed class or involuntary status. Most people can become citizens or residents; a Negro cannot become Caucasian, and a person who was born in another land cannot acquire native grandparents. Yet the courts have occasionally sustained even qualifications based upon an involuntary status or closed class. ${ }^{25}$

Two qualifications which have been particularly troublesome with regard to welfare benefits are indigency and residence. It is not unreasonable for a community to decide that preference should be given in the disbursement of a limited welfare fund to those who are really needy, and

24 For a thorough discussion of the nature, effect, and constitutionality of various residence qualifications upon welfare benefits, see Harvith, The Constitutionality of Residence Tests for General and Categorical Assistance Prograns, this symposium.

25 The classic example is Goesaert v. Cleary, 335 U.S. 464 (1948), sustaining a Michigan statute restricting employment as a barmaid to those women who were the wives or daughters of male owners of licensed taverns or other liquor establishments. Although the Court conceded that "Michigan cannot play favorites among women without rhyme or reason," id. at 466 , its majority concluded that a plausible basis for the classification had been shown, even though entry into that class was really not subject to the applicant's volition. Id. at 466-67. But of. Morey v. Doud, 354 U.S. 457 (1957), a later and somewhat different treatment of the problem of the closed or involuntary class. 
to those who have been members of the community for a substantial length of time. But determination of indigency may involve the use of a means test, the constitutionality of which has recently been drawn in question. ${ }^{20}$ And the residence qualification, particularly where designed to exclude needy newcomers from the community altogether, may conflict with the United States Supreme Court's view of how far a state may go in insulating its treasury from the claims of indigent migrants. ${ }^{27}$

Certain benefit programs require an applicant to supply information in connection with his application. Undoubtedly the government which gives away money has a valid interest in knowing the correct name and home address of everyone to whom it makes payments. But what of information about the applicant's marital status, or the nature of his employment, which may be pertinent to some programs, but not to others? Requests for information about an indigent applicant's income and assets, while innocent enough to the middle-class eye, may have deterred thousands of elderly poor persons from seeking medical attention they obviously needed. ${ }^{28}$

Most troublesome liave been requests for information about political affihations. Even an open-ended question about past membership in political groups may discourage the benefit-seeker and deter future applicants from questionable affiliations. Inquiries about present political associations may force applicants to the choice of declining the benefit or disaffiliating with organizations which are thought suspect. Even these few illustrations suggest, therefore, that inquiries ostensibly seeking only particular, specific information may have collateral consequences far beyond the process of supplying the requested information..$^{20}$

${ }^{26}$ For a trenchant discussion of the constitutional questions raised by the means test and other similar exactions, see Bendich, Privacy, Poverty and the Constitution, this symposium.

27 See Edwards v. California, 314 U.S. 160 (1941); Meyers, Federal Privileges and Immunities: Application to Ingress and Egress, 29 CORNELI L.Q. 489 (1944); Roback, Legal Barriers to Interstate Migration, 28 CORNELI L.Q. 286, 483 (1943); Note, Depression Migrants and the States, 53 HARv. L. REv. 1031 (1940).

${ }^{28}$ For a discussion of some of the effects of the means test, see tenBrock \& Wilson, Public Assistance and Social Insurance-A Normative Evahation, 1 U.C.L.A.L. REv. 237, 264-67 (1954).

29 The most important case invalidating such a merely informational request made of a public beneficiary is Shelton v. Tucker, 364 U.S. 479 (1960). The Supreme Court there struck down as violative of the freedom of association an Arkansas statute requiring every public school or college teacher to file annually an affidavit listing every orgamization to which he had belonged or regularly contributed within the preceding five years. The Court stressed the danger, or at least the fear, that disclosure of unpopular or "disapproved" affiliations might jeopardize the teacher's nontenure position; the probable deterrence of such a requirement to free political association and affiliation; and the sweeping, unqualified scope of the statute's demand. Cf. Lamont v. Postmaster General, 381 U.S. 301 (1965). 
Some inquiries go beyond specific information, moreover, and call upon the applicant to make a subjective judgment about his affiliations. Illustrative is the demand for a declaration that the applicant belongs to no "subversive organizations" or to any group which advocates the violent overthrow of the government. Even when a requirement of "knowing" membership is added, the judgment may be a treacherous one for the layman to make. Thus the broader the question and the less precise the information sought, the more likely is the question to have collateral deterrent effects upon the political activity of the applicant. ${ }^{30}$

Similar though perhaps more acute problems of judgment are raised by demands for an applicant's declaration about or renunciation of certain future political activity. The typical loyalty oath is a prime example, and will be considered more fully below. Another illustration is the ban imposed on public employees' partisan political activity by the federal Hatch Act ${ }^{31}$ and similar state legislation. ${ }^{32}$ Such a ban may be imposed either in the form of an explicit declaration, or by a renunciation implicit in the mere acceptance of any government employment in the covered class. There are various other forms of the "I shall not ... so long as I receive the "benefit" condition, but these two illustrations will suffice for the moment.

Some benefit programs seek an affirmative undertaking on the part of the beneficiary. A student who has part of his higher education financed by the R.O.T.C., or all of it subsidized through attendance at a service academy, thereby obligates himself to serve in the armed forces for a certaim period after graduation. A recipient of National Defense Education Act assistance may turn the loan into a grant-and thus receive an additional benefit of value-by becoming a school teacher for a certain period after college. ${ }^{33}$ These conditions are innocent enough. But consider the more difficult case of the recipient of aid for dependent children who must agree to prosecute the errant father of her children for nonsupport if and when he can be located. In all these cases, the condition is pertinent

30 See, e.g., Baggett v. Bullitt, 377 U.S. 360, 371-73 (1964); Cramp v. Board of Pub. Instruction, 368 U.S. 278, 287 (1961); Wieman v. Updegraff, 344 U.S. 183, 190 (1952); Danskin v. San Diego Unified School Dist., 28 Cal. 2d 536, 548-50, 171 P.2d 885, 893 (1946); Collings, Unconstitutional Uncertainty-An Appraisal, 40 CORNELI L.Q. 195, 219-20 (1955); cf. Pollitt, Statutory Comment, Campus Censorship: Statute Barring Speakers From State Educational Institutions, 42 N.C.L. Rev. 179, 186-96 (1963).

31 See note 56 infra and accompanying text.

32 For a discussion of local and state legislation similar to the Hatch Act, see material cited in note 57 infra.

33 National Defense Education Act $\S 205$ (b)(3), 72 Stat. 1584 (1958), 20 U.S.C. $\S 425$ (b) (3) (1964), provides for the cancellation of up to one half of the entire loan for service as a full-time teacher in a public or other nouprofit secondary or elementary school, at the rate of ten per cent per complete academic year of such service. 
to the program of which the benefit is a part. But the acceptance of the condition may nevertheless exact of the beneficiary a heavy price, and one that may not be fully appreciated at the time the application is made.

Finally, there are conditions which demand no affirmative act of the applicant at the start, but which erode his future protection by relinquishing to the government certain rights which could not have been withdrawn directly. For example, a welfare recipient may have to consent to certain kinds of searches that would otherwise violate his constitutional right of privacy..$^{34}$ Of course, some legal protections simply cannot be bargained away, and public policy will invalidate a state's attempt to exact sucli a waiver. In the meantime, however, the in terrorem effect of mere acceptance of such a condition cannot be overlooked-particularly in the case of the indigent and uncounselled welfare recipient.

One other distinction should be noted among conditions that may encumber government benefits. Some conditions are explicit and obvious to the applicant, even if their significance is not always fully apparent. This is the case where one must sign a loyalty oath before starting work, or must disclose certain information before his application is processed. Other conditions, however; may be more subtly inposed or accepted by acquiescence. The recipient of a radio or television hicense, for example, does not in terms agree to comply with the "fairness" doctrine, not to censor political broadcasts, and the like, but he is as mucli on notice of the policies of the FCC and the provisions of the Communications Act as though he had taken such an oath. That is no great hardship for the well-counselled businessinan. But it may be unreasonable to expect the indigent welfare recipient to anticipate the forfeiture of his benefits for doing or failing to do certain things which are enumerated only in administrative rulings or regnlations, or buried in the pages of a compendious code. Thus, as we shall consider more fully below, the form in which a condition is imposed may often be as significant as its substance. ${ }^{35}$

34 There is considerable doubt whether such an essentially involuntary "consent" will be valid. For a discussion of the difficult constitutional questions, see Reich, Midnight Welfare Searches and the Social Security Act, 72 YALE L.J. 1347, 1348-50 (1963).

35 No survey of the types of conditions attached to government benefits withm the United States would be complete without some reference to the various conditions attached to our foreign aid and international development programs. Some conditions are, of course, obvious in their relationship to the purposes of the program to which they are attached-i.e., military assistance is available only for military expenditures, for the purposes of peace and stability; development loans and grants are available only for specified purposes, and so on. More controversial are the other forms of conditions designed to achieve purposes less immediately related to the aims of the aid or development program itself. There are, for example, conditions designed to make aid administrators act more wisely in accomplishing aid purposes than the Congress beheves they will act without restrictions-e.g., the provision of 75 Stat. 442 (1961), as amended, 22 U.S.C. \& 2361(a)(1) (1964), that funds should not 


\section{III}

\section{THE RATIONALE OF CONDITIONS: WHY GOVERNMENTS IMPOSE RESTRICTIONS ON BENEFITS}

Conditions or qualifications on benefits may serve a broad range of governmental interests and purposes. The stated purpose, if any, for imposing a condition may of course not be the real purpose; both silence and dissimulation may make it difficult to determine the real purpose or motive behind a particular condition. ${ }^{36}$ But a survey of the various conditioned benefit programs suggests certain common objectives. Among such general purposes would undoubtedly appear the following:

be obligated for projects requiring substantive teclinical and financial planning until such planning is done and a reasonably firm estimate of the cost to the Umited States is developed; and the provisions of 75 Stat. 426 (1961), as amended, 22 U.S.C. $\S 2161$ (e) (1964), and 76 Stat. 257 (1962), as amended, 22 U.S.C. \$ 2211(e) (1964), which require application by the country and some planning evaluation before funds are reserved for assistance.

Other conditions attached to American aid funds are designed to achieve a variety of domestic policy objectives: 75 Stat. 439 (1961), 22 U.S.C. $\$ 2354$ (a) (1964), generally limits procurement with appropriated funds to the United States; 75 Stat. 439 (1961), 22 U.S.C. $\S 2354$ (d) (1964), precludes discrimination against the United States marine insurance industry in A.I.D. financed transactions; and 75 Stat. 444 (1961), as amended, 22 U.S.C. $\S 2370$ (d) (1964), prohibits assistance to productive enterprises which are competitive with U.S. enterprises.

Other conditions are designed to prevent aid from going to countries which are politically unacceptable to the United States or which are acting so as to jeopardize United States private investors or other interests. For example, 75 Stat. 444 (1961), as amended, 22 U.S.C. \& 2370 (Supp. I, 1965), is largely concerned with prohibiting aid to various Communist bloc or Comnumist-dominated countries (except for very limited Presidential waiver provisions contained in 75 Stat. 444 (1961), as amended, 22 U.S.C. § 2370(f) (1964), which in a sense place "conditions upon the condition"). 75 Stat. 436 (1961), as amended, 22 U.S.C. \$ 2314 (1964), seeks to limit military assistance to free-world allies; and the Battle Act (Mutual Defense Assistance Control Act of 1951), 65 Stat. 645 (1951), as amended, 22 U.S.C. $\& 1611 b$ (b) (1964), requires the termination of assistance to countries that knowingly permit shipment to Commumist bloc nations of certain categories of strategic materials.

30 The discernment of legislative purpose or intent is always a treacherous business. For a profound analysis of nuany of the problems, see Wofford, The Blinding Light: The Uses of History in Constitutional Interpretation, 31 U. CHI. L. REv. 502 (1964). The attempt is not futile, however. For some cases in which the United States Suprene Court has considered and determined the (or $a$ ) legislative purpose, see, e.g., McLaughlin v. Florida, 379 U.S. 184, 193 (1964); Griffin v. County School Board, 377 U.S. 218, 231-32 (1964); Kennedy v. Mendoza-Martinez, 372 U.S. 144, 170-84 (1963); United States v. Butler, 297 U.S. 1, 68-78 (1936). While Butler's reliance, 297 U.S. at 90, for inquiry into legislative motive upon the now discredited principle of the Child Labor Tax Case, 259 U.S. 20 (1922), may lave been undermined by Umited States v. Darby, 312 U.S. 100, 114-15 (1941), the deference which Darby accords to the legislative judgment, regardless of motive or purpose, apphes particularly to Comnerce Clause cases. Darby does not necessarily preclude inquiry into legislative purpose to determine validity of statutes affecting racial or religious equality, or freedoms of expression and association. Indeed, any doubts about Darby's encroachment upon that judicial domain slrould have been resolved by Mendoza-Martinez, in which judicial determination of legislative motive was the principal basis for invalidating the statute. 


\section{Gather Relevant Information}

Some conditions or qualifications only seek general information necessary in the administration of the program. Where such information cannot affect the status or eligibility of the individual recipient, its gathering is unlikely to deter acceptance of benefits. But where the information does remain in the individual recipient's file, or where the very act of giving the information offends or embarrasses the applicant, it may be difficult to serve even this relatively innocuous purpose without to some degree deterring acceptance of benefits.

\section{Ensure that Benefits Are Restricted to Eligible Applicants}

Many conditions and qualifications seek to ascertain that the benefits go only to those who need them or are qualified to enjoy them. It seems

Some benefit programs demand affirmative undertakings on the part reasonable enough to determine that a scholarship applicant is really a student, that a social security claimant has reached the retirement age, and that a doctor is medically trained and skilled before he can begin to practice. The legitimacy of other conditions and qualifications designed to narrow the channels of distribution of official largesse depends, of course, upon the validity of the criteria of eligibility. Even with qualifications which are obviously legitimate; there may be some question whether the amount or type of information sought is really necessary to determine eligibility, but such questions do not concern us at this stage.

\section{Reduce the Cost of the Program}

Some conditions and qualifications which appear only to determine eligibility may in fact be designed for the ulterior though closely related purpose of economy. Although evidence is very difficult to gather, there are occasional impressions from legislative history and extra-legislative statements that the real inotive for imposing conditions may be to deter or exclude persons who are in fact eligible, and thus reduce the cost of the program. Indeed, the imposition of conditions may constitute one of the subtlest and most effective ways of doing precisely this.

\section{Promote a Strong Governmental Interest}

Apart from the immediately related interests in economy and in res stricting benefits to those for whom they were intended, conditioned benefit programs may seek to achieve a host of other governmental objectives. It would be pointless to catalogue those interests here. It will be sufficient for the moment to suggest two general distinctions: First, between pur- 
poses directly relevant to the benefit program itself and those which are independent or unrelated; and second, between those governmental interests which would support direct regulation of the behavior covered by the condition, and those which would not. As will be suggested below, relevance and the availability of direct regulatory power both bear upon the validity of conditions, though neither should be dispositive.

\section{Promote Loyalty or Deter Disloyalty}

The hardest constitutional questions about conditioned government benefits have involved loyalty oaths and disloyalty bars. Two points should be made here: First, loyalty to the dispensing government is undoubtedly more relevant to certain benefits-for example, security clearances for work in top secret defense programs ${ }^{37}$ - than to others such as residence in public housing projects and receipt of tax exemptions. ${ }^{38}$ The difference between the underlying government interests in these two examples is the difference between protection of highly sensitive programs which could be jeopardized by disloyal persons, and the use of random methods to promote "loyalty" regardless of the nature of the program.

The other point is that the significance of loyalty conditions may depend a great deal upon the form in which they are imposed. Persons of impeccable loyalty and integrity may be deterred from signing sweeping loyalty oaths; indeed, they are probably more likely to refuse the benefit by renouncing the condition than the disloyal persons at whom the condition is ostensibly directed. On the other hand, persons of conscience and scruple are probably less likely to refuse benefits available only to the loyal when they are told that they would forfeit the benefits only if their

37 It is relatively easy, for example, to perceive the interest behind the provisions for security clearance of contractors and licensees working with restricted data from Atomic Energy Commission files, 68 Stat. 942 (1954), as amended, 42 U.S.C. § 2165 (1964). Less obvious is the federal interest in requiring security clearances of all participants in the Peace Corps, 75 Stat. 624 (1961), 22 U.S.C. \$ 2519 (1964). Considerably less apparent is California's interest in requiring a loyalty oath of persons occasionally employed as models for art classes at a junior college-but models, like other employees of the college, are covered by the general loyalty oath requirements, Cax. Gov'T Cope § 18150. See San Francisco Chronicle, Marclı 25, 1966, p. 1, col. 4-5, p. 7, col. 1-2.

88 See the pointed comment of the General Counsel of the Department of Health, Education and Welfare: "Perhaps the chief motive for the imposition of such conditions [loyalty oaths and quahifications] is a feeling that the government ouglnt not to be required to lielp those who would overthrow it. But while ingratitude to a generous government may well be a sin, the fact remains that the first amendment protects ingrates as well as the grateful and, as the Jehovah's Witness cases abundantly testify, the cantankerous as well as the meek." Willcox, Invasions of the First Amendment Through Conditioned Public Spending, 41 CORNEIL L.Q. 12, 48 (1955). For a survey of some of the curious forms of loyalty requirements adopted in the 1950's, and sone observations about their relevance to governmental interests, see $i d$. at $48-52 \& \mathrm{nn} .146-51$; note 111 infra. 
disloyalty were proved in court. ${ }^{39}$ This is a point to which we shall return later.

\section{Ambiguous or Multiple Purposes}

Some cases disclose no declared purpose for the conditioning of government benefits. In other cases the conditions may serve multiple and not always harmonious purposes. It has been said, for example, that the Job Corps administered by the Office of Economic Opportunity systematically refuses to accept applicants with criminal records. ${ }^{40}$ Perhaps the administrators simply feel that former delinquents are bad risks and might disrupt the training camps. Or perhaps they believe that federal funds ought to be used first to train those whose untarnished records show them to be deserving citizens. Or perhaps there is some element of deterrence at work, assuming that if a criminal record will disqualify one for the Job Corps; and if the Job Corps is considered desirable, some dehinquency might thus be prevented. Any or all of these purposes might explain the disqualification $\mathrm{m}$ question. Or perhaps, out of unfamiliarity with the practical administration of the Job Corps, we have missed the real purpose of the dehinquent-disqualification rule which differs from any of the foregoing. Suffice it to say that discernment of the real legislative motives is not always easy.

\section{IV \\ EVOLUTION OF THE LAW OF UNCONSTITUTIONAL CONDITIONS ${ }^{41}$}

The unconstitutional conditions doctrine originated with the case of the foreign corporation seeking permission to do local business. The

\footnotetext{
39 See Justice (as he then was) Traynor's comment: "There are some who refuse to make the required declaration, not because they advocate overthrow of the government, but because they conscientiously believe that the state has no right to inquire into matters so intimately touching political belief. Rightly or wrongly they fear that such an inquiry is the first step in censorship of unpopular ideas." First Unitarian Church v. County of Los Angeles, 48 Cal. 2d 419, 447, 311 P.2d 508, 525 (1957) (dissenting opinion), rev'd, 357 U.S. 545 (1958).

The New York Times has recently observed editorially, apropos the loyalty oath required of certain applicants for Medicare under the 1965 legislation: "Furthermore ... [loyalty oaths] are useless; for what genuine subversive would hesitate to swear loyalty if to do so served his purpose? Only the conscientious are likely to be the victims. A byproduct in the McCarthy heyday of loyalty oaths was that many thinking people in such fields as teaching and the sciences simply bowed out rather than subject themselves to this humiliation." N.Y. Times, Jan. 17, 1966, p. 46, col. 2.

40 Reich, Individual Rights and Social Welfare: The Emerging Legal Issues, 74 YaxE L.J. 1245, 1251 (1965).

41 Probably the most thorough history of the development of the doctrine of unconstitutional conditions is in Willcox, supra note 38, at 22-44. See also, for general discussions, Henderson, The Position of Foreign Corporations in American ConstituTIONAL LAw 132-47 (1918); Hale, Unconstitutional Conditions and Constitutional Rights, 35 Coluar. L. Rev. 321 (1935); Merill, Unconstitutional Conditions, 77 U. PA. L. REv. 879 (1929); Note, Unconstitutional Conditions, 73 Harv. L. REv. 1595 (1960).
} 
claimed basis of authority to impose conditions upon the entry of such a corporation was the nondomiciliary state's absolute power to exclude all corporations from the local market. In 1877 the Supreme Court held that Wisconsin could oust a foreign corporation for having removed a case to the federal court in violation of a condition of entry because the corporation "has no constitutional right to do business in that State; that State has authority at any time to declare that it shall not transact business there." ${ }^{32}$ There were dissents, even in the beginning. In the case just cited, for example, Justice Bradley challenged the majority's assumption that "the greater always includes the less" and termed "unsound" the conclusion that "if the State may exclude the ... [corporation] without any cause, it may exclude them for a bad cause . . . ."43

The critical turning point came in 1926, when the Court held that California could not require a foreign trucking corporation to accept the status of a common carrier in order to do business in the state as a contract carrier. ${ }^{44}$ Although declining to repudiate the old view completely, the Court declared simply that "the power of the State in that respect is not unkimited; and one of the limitations is that it may not impose conditions which require the relinquishment of constitutional rights." 145

Until quite recently, the foreign corporation cases have set the pattern. They have generally determined what conditions are reasonable under the constitutional standard. But there have not been many such cases of late-wliether because the states lave become more subtle in their regnlation of entry by foreign corporations, or because the courts have been less anxious to protect such corporations from state regulation. ${ }^{46}$

The center of the unconstitutional conditions stage has now been taken over by the newer problems with which we are concerned in this articlegovernment employment, education, licensing, and welfare benefits. Despite the significant differences between these activities and government regulation of foreign corporations, substantially the same principles have usually been invoked. The results of this curious assimilation have been, as we shall see, far from satisfactory.

The confusion about applying the unconstitutional conditions doctrine outside the foreign corporations area is well illustrated by the quandary of Mr. Justice Holmes. It was Holmes who once insisted, in defense of a city's ban on political activities by certain of its employees, that a police

42 Doyle v. Continental Ins. Co., 94 U.S. 535, 542 (1877).

43 Id. at 543-44 (dissenting opinion).

44 Frost \& Frost Trucking Co. v. Railroad Comm'n, 271 U.S. 583 (1926). But cf. Stephenson v. Binford, 287 U.S. 251 (1932), for assurance that Frost did not represent total repudiation of the old doctrine.

45 Frost \& Frost Trucking Co. v. Railroad Comm'n, supra note 44, at 593-94 (1926).

46 For a discussion of the continuing vitality of the foreign corporation-conditioned .entry cases, see Note, Unconstitutional Conditions, 73 HaRv. L. Rev. 1595, 1605-09 (1960). 
officer "may have a constitutional right to talk politics; but he has no constitutional right to be a pohiceman." ${ }^{37}$ It was Holmes, too, who (as a state judge) saw no great constitutional difference between a city's absolute refusal to open its parks for speeches and rallies, and its conditioning of such use upon a permit granted by the mayor in his unfettered discretion. $^{48}$

It was also Justice Holmes, however, who balked when a majority of the Court deemed the fourth-class mailing privilege a gratuity which the Post Office Department might grant or deny arbitrarily. "The United States may give up the Post Office when it sees fit," warned Holmes, "but while it carries it on the use of the mails is ahnost as much a part of free speech as the right to use our tongues ...." ${ }^{39}$ Here is the essence of the modern notion of unconstitutional conditions. It was particularized, though, in Justice Brandeis' dissent in the same case. "Congress may not through its postal pohice power," declared Brandeis, "put limitations upon the freedom of the press which if directly attempted would be unconstitutional.".50

When a similar question of the use of low cost mailing privileges came before the Court two decades later, the majority was ready to accept the Holmes-Brandeis view:

[G]rave constitutional questions are immediately raised once it is said that the use of the mails is a privilege which may be extended or withheld on any grounds whatever. ... Under that view the second-class rate could be granted on condition that certain economic or political ideas not be disseminated. The provisions of ... [the statute] would have to be far more explicit for us to assume that Congress made such a radical departure from our traditions and undertook to clothe the Postmaster General with the power to supervise the tastes of the reading public of the country. ${ }^{51}$

Given such statements, one might suppose that the unconstitutional conditions doctrine today consistently protects the recipient of government benefits. That is still far from the case, however, as a quick review of recent Supreme Court decisions will indicate. In the field of public employment, for example, the Court first held that states may demand loyalty oaths as a condition of obtaining and holding a government job. ${ }^{52}$

47 McAuliffe v. Mayor \& Board of Aldermen, 155 Mass. 216, 220, 29 N.E. 517 (1892).

48 Commonwealth v. Davis, 162 Mass. 510, 39 N.E. 113 (1895). The Supreme Court affirmed the conviction in Davis v. Massachuetts, 167 U.S. 43 (1897), finding nothing unconstitutional in the conditional exercise or the discretionary delegation of the city's power to deny all use of its parks for public expression.

49 Milwaukee Social Democratic Publishing Co. v. Burleson, 255 U.S. 407, 437 (1921) (dissenting opinion).

50 Id. at $430-31$.

51 Hannegan v. Esquire, Inc., 327 U.S. 146, 156-57 (1946).

52 Garner v. Board of Pub. Works, 341 U.S. 716 (1951). 
But subsequent cases have invalidated various types of loyalty oaths as excessively broad or uncertain, ${ }^{53}$ or for failure to deal only with knowing membership in the proscribed organizations. ${ }^{54}$ The federal Hatch Act, ${ }^{55}$ which drastically curtails the political activities of civil servants, has been upheld; ${ }^{50}$ but similar county charter provisions have been struck down by at least one state suprenre court on federal constitutional grounds..$^{57}$

The United States Suprenie Court permitted the termination of social security benefits because the beneficiary was deported on grounds of pohitical activity that would have caused no forfeiture either at the tinie the activity occurred or at the time the beneficiary was first covered by social security..$^{58}$ Yet, a few years later, the Court held that a state might not constitutionally deny unemployment compensation to a Seventh-Day Adventist who was declared unavailable for suitable work only because her rehgion prevented her from accepting Saturday employment. ${ }^{59}$ In the field of public education, the Court has never overruled its 1934 decision permitting the University of Cahfornia to condition admission on willingness of students to take at least two years of R.O.T.C. training ${ }^{60}$ although the rationale of that decision is difficult to square with nore recent pronouncements on public education. ${ }^{61}$

Finally there is the bizarre series of cases dealing with admission to

53 Baggett v. Bullitt, 377 U.S. 360 (1964); Cramp v. Board of Pub. Instruction, 368 U.S. 278 (1961).

54 Wieman v. Updegraff, 344 U.S. 183, 190 (1952). Cf. Elfbrandt v. Russell, 86 S. Ct. 1238 (1966).

6553 Stat. 1148 (1939), as amended, 5 U.S.C. § 118i (1964): "No officer or employee in the executive branch of the Federal Government, or any agency or department thereof, shall take any active part in pohtical management or in political campaigns."

56 Umited Pub. Workers v. Mitchell, 330 U.S. 75 (1947).

57 Fort v. Civil Serv. Comm'n, 61 Cal. 2d 331, 38 Cal. Rptr. 625, 392 P.2d 385 (1964); Kinnear v. City \& County of San Francisco, 61 Cal. 2d 341, 38 Cal. Rptr. 631, 392 P.2d 391 (1964).

58 Flemming v. Nestor, 363 U.S. 603 (1960).

59 Sherbert v. Verner, 374 U.S. 398 (1963).

60 Hamilton v. Regents of the Univ. of Calif., 293 U.S. 245 (1934). On the logical difficulty of reconciling Hamilton with later cases such as Sherbert, see Linde, Justice Douglas on Liberty in the Welfare State: Constitutional Rights in the Public Sector, 40 WASE. L. REv. 10, 19-22 (1965).

01 See, e.g., Griffin v. County School Board, 377 U.S. 218 (1964); School Dist. of Abington Township v. Schempp, 374 U.S. 203 (1963). Although these cases deal with elementary and secondary education rather than the higher education with which Hamilton was concerned, other cases indicate the changing attitudes of the Court with respect to higher education. See, e.g., McLaurin v. Oklahoma State Regents, 339 U.S. 637 (1950); Sweatt v. Painter, 339 U.S. 629 (1950); Sipuel v. Board of Regents, 332 U.S. 631 (1948), reversing, 119 Okla. 36, 180 P.2d 135 (1947); Dixon v. Alabama State Board of Educ., 294 F.2d 150 (5th Cir.), cert. denied, 368 U.S. 930 (1961); Knight v. State Board of Educ., 200 F. Supp. 174 (M.D. Tenn. 1961); Van Alstyne, Student Academic Freedom and the Rulemaking Powers of Public Universities: Some Constitutional Considerations, 2 LAW IN TRANSTrTon Q. 1, 6-8 (1965). 
the bar. At the close of World War II the Court sustained Illinois' power to refuse admission to an applicant solely because he would not promise to bear arms in support of the state. ${ }^{62}$ Twelve years later the Court held that a state bar could not reject an otherwise qualified applicant simply on suspicion he had been a Communist-at least not on grounds of "bad moral character." ${ }^{\prime 63}$ At that time the Court declined to classify bar admission as a "right" or a "privilege," but indicated only that it was an opportunity of sufficient importance to the individual that it could not be arbitrarily withheld. ${ }^{64}$ Yet within a few years the Court seemingly abandoned that view by allowing a state to reject a bar applicant who refused to answer questions about his alleged past Commumist affiliations. ${ }^{65}$

The course of these decisions is far from consistent, and makes it hazardous to predict future developments. This background suggests that if the case law governing conditioned benefits in public employment, education, and licensing is now uncritically transferred to the burgeoning field of conditioned public welfare benefits, the results could be most unfortunate. Before such a transfer is inade, therefore, it seems essential to formulate more rational, more discriminating, and more appropriate principles for judging the constitutionality of conditioned benefits.

\section{A SUGGESTED FRAMEWORK FOR TESTING CONDITIONED BENEFITS}

Two legal premises underlay the old view that government could impose virtually any condition it wished upon the offer or grant of a benefit. The first premise was that government is not constitutionally compelled to extend any benefits. ${ }^{66}$ The second premise was that given the power of total exclusion or flat denial, the government could exercise the "lesser" power of making the benefit available only on certain condi-

62 In re Summers, 325 U.S. 561 (1945).

${ }^{63}$ Schware v. Board of Bar Examiners, 353 U.S. 232 (1957); Konigsberg v. State Bar, 353 U.S. 252 (1957).

64 Schware v. Board of Bar Examiners, supra note 63, at 239 n.5.

65 Konigsberg v. State Bar, 366 U.S. 36 (1961). The Court stressed that the applicant was disqualified by his failure to respond candidly to the questions, and not any inference about his past political affliations. Cf. Slochower v. Board of Higher Educ., 350 U.S. 551 (1956), which led to his rejection. But of., for a still later, and somewhat different view of the constitutional status of admission to the bar, Willner $v$. Committee on Character and Fitness, 373 U.S. 96, 102 (1963).

06 This premise would not apply, of course, to any benefits decmed "rights" rather than "privileges." But in the early days few, if any, government benefits were held to be "rights" that could not constitutionally be withdrawn or denied. Even the franchise, which was not extended to all citizens, and upon which qualifications were widely imposed, was presumably a "privilege" rather than a "right." If the franchise could be demied or withdrawn, then a fortiori government was not obligated to extend to all citizens, without qualifications, such other benefits as employment, education, and welfare payments. 
tions. ${ }^{67}$ It mattered not, therefore, whether the dispensing government could constitutionally have achieved the same objective by direct regulation, for the beneficiary always had the theoretical option of avoiding the indirect regulation by refusing the benefit.

The first of these premises has been trenchantly criticized by Professor Charles Reich in his recent articles. ${ }^{68}$ His theory of "entitlement" suggests that even welfare benefits are no longer gratuities but have assumed at least some of the characteristics of "rights." If that argument prevails, it may be unnecessary even to consider the second premise or the question whether government may achieve indirectly what it cannot accomplish directly.

But there is some doubt how the Reicl theory of "entitlement" will fare in the courts. ${ }^{69}$ Thus it is still worth tackhing the second premise; that given the "greater" power of exclusion, government can exercise the "lesser" power of conditioning admission. Half a century ago Professor Thomas Reed Powell argued forcefully that there is no principle of logic which comprehends the power to impose any conditions whatever within the power to exclude or refuse benefits unconditionally. ${ }^{70}$ Yet the fallacy persisted, perhaps because exposure of bad logic is not always an antidote for stare decisis. ${ }^{71}$

There are other flaws, moreover, in the logic of this second premise. To say that because government can exclude an applicant or deny a benefit summarily, and without giving reasons, it can grant or admit on any

67 See Davis v. Massachusetts, 167 U.S. 43, 48 (1897): "The right to absolutely exclude all right to use, necessarily includes the authority to determine under what circumstances such use may be availed of, as the greater power contains the lesser." See notes 11, 48 supra.

08 Reich, The New Property, 73 YAIE L.J. 733 (1964); Reich, Individual Rights and Social Welfare: The Emerging Legal Issues, 74 Yare L.J. 1245 (1965). See also the thoughtful criticism of the Reich theories by Professor Joel Handler. Handler, Controlling Official Behavior in Welfare Administration, this symposium.

69 It should be apparent that the Reich theory tends to accept the right-privilege distinction, by turning that distinction to the advantage of welfare recipients and applicants. Professor Bendich seems to view the problem in a similar light, for he also argues that certain benefits have become "rights" and cannot be treated as gratuities any longer. See Bendich, supra note 24. For reasons discussed earlier in this article, however, it may be sounder to reject altogether the right-privilege distinction, or-as the courts have tended increasingly to do-simply to disregard it on the theory that the clain involved, whether one of right or privilege, is entitled to major constitutional safeguards. See, e.g., Schware v. Board of Bar Examiners, 353 U.S. 232, 239 \& n.5 (1957) ; Slochower v. Board of Higher Educ., 350 U.S. 551, 555-56 (1956); Wieman v. Updegraff, 344 U.S. 183, 192 (1952).

70 Powell, The Right To Work for the State, 16 Coluns. L. REv. 99, 110-12 (1916). For a more modern indictment of the "privilege" notion, see French, Comment: Unconstitutional Conditions: An Analysis, 50 GEo. L.J. 234, 239-42 (1961).

71 See, e.g., Adler v. Board of Educ., 342 U.S. 485, 492 (1952); Anerican Communications Ass'n v. Douds, 339 U.S. 382, 408 (1950) ; Thompson v. Gleason, 317 F.2d 901, 906 (D.C. Cir. 1962) ; cf. Flemming v. Nestor, 363 U.S. 603, 608-10 (1960). 
condition, is analogous to the argument that the government may use its undoubted power to instantly execute a convicted killer as the basis for killing him by slow torture. Obviously the doctrine of cruel and unusual punishment intercedes, recognizing that the greater power does not always include the lesser..$^{72}$ Or, to take another analogy, the undoubted power of a businessman to close down altogether in order to prevent labor unionization does not give him the "lesser" power to close down part of his business for that purpose, or to transfer struck work to another plant, or to take various other seemingly less drastic antiunion measures. ${ }^{73}$

The arguments against the greater-includes-the-lesser theory in the conditioned benefits field are also quite strong. Most important is the psychological impact of merely offering a conditioned benefit. The unexplained denial of a benefit will probably not deter any conduct other than the enjoyment of the benefit itself. But where conditions are imposed or reasons are given, the natural human response is to be influenced by the condition or qualification itself, unless of course the benefit is either worthless or readily available elsewhere without conditions. Thus the very fact of attaching the conditions to government benefits probably influences human conduct more extensively than the flat denial or withdrawal of the benefit, not less. Regardless of whether one is a "greater" government power than the other, it should be apparent that these are very different forms of regulation with quite distinct effects upon prospective beneficiaries.

Thus the "greater" power to withhold the benefit does not logically subsume the "lesser" power to grant it conditionally. But this does not, of course, mean that all conditions are constitutionally bad. Indeed; many conditions are legitimate, and some (such as the condition that federal grants to the states not be spent for racially discriminatory programs ${ }^{74}$ ) may even be constitutionally required..$^{75}$ The problem for the constitutional scholar is to differentiate the valid from the invalid conditions. This task requires a more discriminating and more uniform set of tools than are now available. We shall consider various questions that might be used to appraise the validity of a particular condition. Undoubtedly no one condition would respond to analysis under all these criteria; only those that are appropriate need be invoked in each instance. The final resolution

72 See Trop v. Dulles, 356 U.S. 86 (1958), in which the Court found that the denaturalization of a person for being a wartine deserter was a cruel and unusual punishment even though he could have been summarily executed for the desertion. $C f$. Robinson v. California, 370 U.S. 660 (1962); Louisiana ex rel. Francis v. Resweber, 329 U.S. 459 (1947).

73 Textile Workers Union v. Darhington Mfg. Co., 380 U.S. 263 (1965).

74 Title VI, Civil Rights Act of 1964, 78 Stat. 252 (1964), 42 U.S.C. $\$ \S 2000 d-2000 d-4$ (1964).

75 See Bolling v. Sharpe, 347 U.S. 497 (1954). 
of the condition's constitutionality might then depend upon a balancing of the results.

\section{A. Could the Object of the Condition Be Achieved Directly?}

It is sometimes said that a conditioned benefit may not be used to bring about a result that the government is powerless to achieve through direct regulation. ${ }^{76}$ In at least two situations this proposition seems sound. First is the case in which government discriminates among beneficiaries along hines that would clearly violate the fourteenth amendment's equal protection clause if the discrimination resulted from direct regulation. ${ }^{77}$ Government may no more discriminate against Negroes, or Catholics, or Mexicans, as such, through conditioned benefits than it may directly impose disabilities upon such groups. ${ }^{78}$

The second case in which the absence of direct power may well be conclusive is the indirect attempt to force the surrender of a right clearly protected by the first amendment. ${ }^{79}$ There is little doubt, for example, that a government could not offer employment on condition that its employees agree not to attend church while so employed. Nor could a state university compel its students to give up all writing or publishing while they remained on the campus. Beyond these obvious cases, though, the siguificance of a lack of direct power is much less clear. The federal Hatch Act, for example, denies to federal civil servants certain important pohtical activities which surely could not be closed to any group of persons employed in the private sector. ${ }^{80}$ Yet the Hatcli Act has been held constitutional, ${ }^{81}$ suggesting that even where the infringements of first amendment rights may be substantial, the absence of governmental power to achieve the same end through direct means is not always dispositive. ${ }^{82}$

${ }^{76}$ See, e.g., Buckley v. Meng, 35 Misc. 2d 467, 475, 230 N.Y.S.2d 924, 934 (Sup. Ct. 1962); cf. Lawson v. Housing Authority, 270 Wis. 269, 275, 70 N.W.2d 605, 608 (1955). More discriminating is the Supreme Court's recognition that "under some circumstances, indirect 'discouragements' undoubtedly have the same coercive effect upon the exercise of First Amendment rights as imprisonment, fines, injunctions or taxes." American Communications Ass'n v. Douds, 339 U.S. 382, 402 (1950).

${ }^{77}$ See Missouri ex rel. Gaines v. Canada, 305 U.S. 337 (1938); Garner v. Board of Pub. Works, 341 U.S. 716, 725 (1951) (opinion of Frankfurter, J.); Bynum v. Schiro, 219 F. Supp. 204 (E.D. La. 1963).

78 See Linde, supra note 60 , at 12 .

79 See, e.g., Thomas v. Collins, 323 U.S. 516, 540 (1945); Danskin v. San Diego Unified School Dist., 28 Cal. 2d 536, 547-48, 171 P.2d 885, 892-93 (1946).

80 See United Pub. Workers v. Mitchell, 330 U.S. 75, 110-11 (1947) (Black, J., dissenting); cf. Fort v. Civil Serv. Cornm'n, 61 Cal. 2d 331, 338, 392 P.2d 385, 389, 38 Cal. Rptr. 625, 629 (1964).

81 United Pub. Workers v. Mitchell, supra note 80.

82 See also French, supra note 70 , at $242-43$, for comments about the logical inadequacy of the notion that absence of direct power precludes the use of indirect means. 
Perhaps the Hatch Act cases should be read more narrowly, however, because of the Court's deference to the government's interest in the integrity of the civil service.

Other cases further undermine the proposition that "government may not do indirectly what it can't do directly." It is highly doubtful, for example, whether the federal government could constitutionally conscript prospective teachers for compulsory classroom service after college graduation. Yet those doubts do not necessarily invalidate the provision of the NDEA loan program which seeks to induce students to sign up for one to five year teaching stints as a condition of partial forgiveness of the debt they incur to finance their higlier education. ${ }^{83}$ These examples demonstrate that the absence of direct power does not always preclude the use of indirect methods.

Indirect inducements are, however, suspect in such cases, and a finding that direct power is lacking should militate against the validity of the condition for several reasons. First, there is the probable difference in procedural safegnards and in the susceptibility of the restriction to judicial challenge. The contrast may be illustrated by recent congressional efforts to bar Communists from leadership positions in the labor movement. In the Taft-Hartley Act, indirect ineans were employed: Section 9(h) made it a condition of resort to the NLRB that the union declare it liad no Communists among its officialdom. ${ }^{84}$ In an early test, the Supreme Court sustained that condition against a barrage of constitutional attacks. ${ }^{85}$ A decade later, in the Landrum-Griffin Act, the Congress substituted criminal penalty for condition by providing for the prosecution of Communist labor leaders. ${ }^{86}$ In its first Supreme Court test, this direct method was held invalid as a bill of attainder ${ }^{87}$ Of course there were other differences between the two cases, but the juxtaposition suggests an important principle: The denial or withdrawal of a conditioned benefit is seldom surrounded with the procedural safeguards that are essential to a criminal prosecution. For this reason, the direct means is constitutionally preferable to the indirect, even where both are permissible.

83 National Defense Education Act $\S 205$ (b) (3), 72 Stat. 1584 (1958), as amended, 20 U.S.C. $\$ 425$ (b) (3) (1964); see note 34 stupra.

84 Labor Management Relations Act § 9(h), 61 Stat. 143 (1947).

85 American Communications Ass'n v. Douds, 339 U.S. 382 (1950). Significantly, the Court did suggest more than once during the opinion that "the loss of a particular position is not the loss of life or liberty." Id. at 409 ; cf. id. at 402.

${ }^{86}$ Labor-Management Reporting and Disclosure Act (Landrum-Griffin Act) § 504, 73 Stat. 536 (1959), 29 U.S.C. § 504 (1964).

87 United States v. Brown, 381 U.S. 437 (1965). Although the Supreme Court struck down the statute as a bill of attainder, the court of appeals had reached the same result under the first and fifth Amendments, Brown v. United States, 334 F.2d 488 (9th Cir. 1964), af'd, 381 U.S. 437 (1965). 
A second consideration is the relative availability of judicial review. One need only recall the difficulty of the New York teachers in getting a constitutional test of the Feinberg law, ${ }^{88}$ or of federal employees in challenging the Hatch Act's political prohibitions on the merits. ${ }^{89}$ It has been widely assumed that many conditions--the loyalty oath under the Medicare program, ${ }^{90}$ and the since repealed affidavit required of NDEA loan recipients, ${ }^{91}$ for example-are simply beyond judicial challenge according to present principles of standing and justiciability..$^{22}$ The fault may lie with the rules of standing, of course, rather than in the use of indirect methods to promote questionable government interests. ${ }^{93}$ But until these barriers to constitutional litigation are relaxed, they afford an additional ground for preferring the direct to the indirect route.

This discussion suggests that the question "could it be done directly?"

88 Adler v. Board of Educ., 342 U.S. 485 (1952).

89 United Pub. Workers v. Mitchell, 330 U.S. 75, 86-91 (1947).

${ }^{80}$ The Medicare program was established by Subchapter XVIII of the Social Security Act, added by 79 Stat. 291 (1965), 42 U.S.C.A. $\$ 1395$ (Supp. 1965). The oath required of applicants for Medicare who have never been covered by Social Security is not part of the statute, but rather an administrative addition to the application form. The oath requires the affected applicant to certify that he is not now, and has not been for the previous twelve months, "a member of any organization which is required to register under the Internal Security Act of 1950, as amended, as a Communist-action organization, a Communist-front organization, or a Communist-infiltrated organization." There have been recent efforts in Congress to obtain the abolition of the oath, strongly supported by the American Civil Liberties Union and other interested groups. See N.Y. Times, Jan. 11, 1966, p. 6, cols. 3 \& 4; Jan. 4, 1966, p. 8, cols. 3 \& 4. Eventually the Commissioner of the Social Security Administration, which originally deemed the oath to be required by the statute, also sought its abohtion by Congress. N.Y. Times, Feb. 10, 1966, p. 50, col. 8.

31 The oath was originally required of all applicants for National Defense Education Act loans by section 1001(f) of the National Defense Education Act of 1958, 72 Stat. 1602 (1958). It was repealed in 1962, 76 Stat. 1069 (1962). In its place was substituted a sinple oath of allegiance requirement, together with a provision compelling applicants to submit lists of all major criminal convictions.

Also of recent interest in this regard is the repeal by Congress of the short-lived requirement that Poverty Progran workers disavow membership in and support of "any organization that believes in or teaches, the overthrow of the United States Government by force or violence or by any illegal or unconstitutional means." Economic Opportunity Act of 1964, § 616, 78 Stat. 533, repealed by 79 Stat. 979 (1965).

92 For recent examples of legislation which purports in terms to preclude judicial review of determinations in public welfare programs, see, e.g., 79 Stat. 59 (1961), 42 U.S.C. § 2514(c) (1964); 76 Stat. 26 (1962), 42 U.S.C. \& 2583 (g) (1964). Not all statutes which purport to make decisions "final" or "unreviewable" are accorded the desired deference by courts asked to review their application. E.g., United States v. California Eastern Line, 348 U.S. 351 (1955); see 4 Davis, AdMomistrative LAW ch. 28 (1958). For some of the practical difficulties involved in obtaining judicial review of decisions denying or withdrawing welfare benefits, see generally Mandelker, Judicial Review in General Assistance, $6 \mathrm{~J}$. Pü. L. 100 (1957); note 123 infra.

${ }^{93}$ Cf. Jaffe, Standing to Secure Judicial Review: Public Actions, 74 HARv. L. Rev. 1265 (1961). 
is still pertinent, even though a negative answer is not dispositive. The use of indirect means to circumvent the absence of direct regulatory power is inherently suspect on several grounds. At the very least, the effect of the condition should be scrutinized more critically where direct power is lacking. Moreover, it might be appropriate to require in such a case that the denial or withdrawal of the benefit be made judicially reviewable through prescribed channels ${ }^{94}$ (to the extent permitted by constitutional limitations on court jurisdiction), and that procedural safeguards of a judicial character accompany any administrative proceeding for such denial or withdrawal. ${ }^{95}$ More will be said below about procedure and judicial review. ${ }^{96}$

\section{B. How Relevant is the Condition to the Benefit?}

Relevance is another deceptively simple criterion the utility of which is exaggerated; not every condition is necessarily invalid because it is not directly relevant to the purposes of the program. Whether the less relevant condition may be sustained despite its attenuation depends upon other factors including the strength of the underlying government interest and the effect of the condition upon the recipient.

Nonetheless, relevance should be an important factor in the balance. A loyalty oath, for example, should be tolerated more readily when it restricts the employment of persons for top secret defense jobs than when it restricts admission to a public housing project. ${ }^{97}$ And, as has often been

$84 \mathrm{Cf}$. the judicial review provision of the Elementary and Secondary Education Act of 1965, Title II, § 211, 79 Stat. 33, 20 U.S.C. § 241k (Supp. I, 1965). In a much earlier proposed statute for federal aid to education, which passed the House but not the Senate, private taxpayers were authorized to bring suit to prevent improper expenditure or to enforce compliance with the statute. H.R. 4643, § 5, 81st Cong., 1st Sess. (1949).

05 $\mathrm{Cf}$. the development of quasi-judicial procedures for the suspension or expulsion of college students who could once be dismissed by the most summary or perfunctory of hearing procedures. See, for examples oi the newer approach, University of Oregon Student Conduct Program, Pt. I, \& A(4) (1964); University of Cahifornia Policies Relating to Students and Student Organizations, Use of University Facihties, and Non-Discrimination, Section II, Pt. E, July 1, 1965.

96 See notes 118-24 infra and accompanying text.

97 See Willcox, Invasions of the First Amendment Through Conditioned Public Spending, 41 CoRneIL L.Q. 12, 49-50 (1955): "Though we can hardly expect the courts to reject loyalty tests as irrelevant to even non-sensitive pubhic employment, their relevance to non-sensitive private employment or occupations financed by the government stands in a quite different posture. Unless in particular situations some reason for such tests can be shown other than the mere fact that the government is footing the bill, it is submitted that the tests, if imposed by government, are unconstitutional conditions in violation of the first amendment." If the test of relevance is uniformly applied, it would be hard to imagine a benefit to which loyalty is less relevant than that of burial in a national cemetery. Yet the Attorney General of the United States recently denied that honor to the remains of one Robert G. Thompson, a decorated World War $H$ veteran who would bave been 
suggested, a test of professional competence may be proper as a condition of admission to legal or medical practice, while a test of political beliefs should be rejected because it is irrelevant. ${ }^{98}$

One might approach the issue of relevance by asking two further questions about a conditioned benefit: (1) How strong is the government's interest in the benefit program? (2) How strong is the government's interest in the activity to which the condition apphes? These two questions cannot, however, really be separated. A government undoubtedly has a stronger interest in deterring professional incompetence in the practice of hicensed professions than in deterring immorality among residents of hoúsing projects. It makes little sense, however, to say abstractly that the government's interest in the licensing of the professions is stronger than its stake in providing low cost shelter for needy citizens; or that ensuring competence is more vital to the functions of government than promoting morality. These statements become meaningful only when a particular condition is judged in relation to a particular benefit; neither the importance of the benefit program nor that of the condition can be evaluated in isolation. It is the criterion of relevance which juxtaposes them in such a way as to facihtate meaningful comparison.

Suppose, however, that the condition is not directly relevant to the program of which the encumbered benefit is a part. Then an alternative question should be asked: Is the condition relevant to some other valid governmental purpose? If it is, the lack of relevance to the program involving the particular benefit may be less serious. To illustrate: When government funds are allocated to assist communities in ending racial

ehgible for burial in the Arlington National Cemetery but for the fact of his conviction as a leading Communist conspirator. He had also been sentenced for jumping bail, but the disqualification for interment was based on his allegedly subversive background. N.Y. Times, Jan. 28, 1966, p. 1, col. 2, p. 11, col. 1-2. Although it is difficult to determine the relevance of this qualification to the federal interest in maintaining the cemetery as a national shrine, at least one observer finds such a relationship. See the recent comment of Representative Charles E. Bennett of Florida: "If this can be justified, we can justify burying there Benedict Arnold, Aaron Burr and a host of others who at one time in their hes contributed something to America, but turned their back on the country that had helped them to secure all the good things they had attained." Los Angeles Times, Jan. 25, 1966, Pt. I, p. 6, col. 2. Similar questions of relevance to the purpose of the benefit program may be raised about the declaration of loyalty required of certain applicants for Medicare benefits. See note 84 sicpra. The disclaimer has been attacked on various grounds in the press, e.g., N.Y. Times, Jan. 17, 1966, p. 46, col. 2, and by the American Civil Liberties Union, N.Y. Times, Jan. 4, 1966, p. 8, col. 3-4. Bills to eliminate it have been introduced both in the House, 112 Cong. Rec. 6-8 (daily ed. Jan, 10, 1966), and in the Senate, 112 Cong. Rec. 344 (daily ed. Jan. 17, 1966). Finally, even the Social Security Administration of the Department of Health Education and Welfare asked Congress to remove any implication of such a requirement. N.Y. Times, Feb. 10, 1966, p. 50, col. 8; see note 90 supra.

88 See, e.g., Barsky v. Board of Regents, 347 U.S. 442, 474 (1954) (Douglas, J., dissenting). 
segregation in the public schools, the condition that such funds not be used for discriminatory purposes is obviously relevant to the whole program. ${ }^{99}$ But when federal funds are appropriated for school construction, or hospital construction, or any of a number of other legitimate federal objectives, the condition of racial nondiscrimination is only remotely relevant to the purpose of the benefit program. ${ }^{100}$ Yet that lack of relevance is not disabling so long as some valid governmental purpose-here the elimination of racial barriers-is furthered by imposing the condition.

Once the relevance of the condition to some legitimate government end is established, a further question should be asked: Is there a rational relationship between the condition and the end sought by the government program of which the benefit is a part? Rationality is not something that courts can easily determine. Yet there are a number of cases in the equal protection field deciding whether a particular classification bears a rational relationship to a governmental interest. ${ }^{101}$ Perhaps the same canons of rationahty can be applied here; courts have occasionally invalidated conditions which were irrationally related to the asserted purpose. ${ }^{102}$ Such decisions are necessarily imprecise, however, and the principle of rationality is unlikely to catch any but the most arbitrary condition. A sounder approach to the rationality of the link between condition and governmental interest may be suggested by the question we next considerwhether there is a better way of doing what the condition seeks to do.

99 Section 405 of the 1964 Civil Rights Act, 78 Stat. 247, 42 U.S.C. \& 2000c-4 (1964), does not expressly condition grants of aid for desegregation upon the assurance that they not be used for discriminatory purposes, but that condition is implicit-apart from the general nondiscrimination guarantee oi Title VI of the Act. See note 23 supra.

100 Since enactment of the 1964 Civil Rights Act, extensive use has been made of federal funds to encourage public school desegregation in the South, Wall St. Journal (SF. ed.), Jan. 24, 1966, p. 1, col. 4, p. 13, col. 1-3, and to reduce racial barriers in hospitals, Wall St. Journal, Feb. 2, 1966, p. 12, col. 4; IN.Y. Times (city ed.), March 9, 1966, p. 26, col. 1-2. A recent report of the United States Civil Rights Commission views with satisfaction the use of federal funds in various programs to speed desegregation. U.S. Conar'N ON CrvnL Rights, TItre VI . . O One Year After (1966). See also THe Potonac Institute, INc., THE FEDERAI, DoLlar and NONDISCRIIITNATION (1965).

101 E.g., McLaughhin v. Florida, 379 U.S. 184 (1964); Morey v. Doud, 354 U.S. 457 (1957).

102 E.g., Komigsberg v. State Bar, 353 U.S. 252, 273-74 (1957); Slochower v. Board of Higher Educ., 350 U.S. 551, 558 (1956); Fort v. Civil Serv. Comm'n, 61 Cal. 2d 331, 337-38, 392 P.2d 385, 389, 38 Cal. Rptr. 625, 629 (1964); Syrek v. California Unemployment Ins. Appeals Bd., 54 Cal. 2d 519, 529-30, 354 P.2d 625, 631, 7 Cal. Rptr. 97, 103 (1960); Housing Authority v. Cordova, 130 Cal. App. 2d 883, 279 P.2d 215 (1955); Chicago Housing Authority v. Blackman, 4 III. 2d 319, 326, 122 N.E.2d 522, 526 (1954); Lawson v. Housing Authority, 270 Wis. 269, 287-88, 70 N.W.2d 605, 615 (1955). The courts in the three cases last cited invalidated as irrational state and federal attempts to deny certain "subversive persons" access to governmentally assisted housing. For a discussion of the application of the rationality test to these cases, see Note, 53 ColUns. L. REv. 1166 (1953). 


\section{What Alternative Means, if Any, Would Achieve the Same End?}

It is now time to consider the potential contribution of the principle of the "less onerous alternative." 103 Where a condition may deter constitutionally protected expression or political activity, courts increasingly hold that government may not employ restrictions more drastic than are absolutely necessary. ${ }^{104}$ Thus, to return to the case of the ban on political activity by civil servants, if the real evil is partisan pressures brought by superiors upon their subordinates, the government interest might be adequately served by direct criminal sanctions against such improper pressures. ${ }^{105}$ Partly on this ground, the California Supreme Court recently invalidated such a condition on public employment; finding no proof of the inadequacy of more precise and direct criminal proscriptions. ${ }^{106}$

The doctrine of the less burdensome alternative is most applicable, of course, to conditions that threaten freedom of expression. But even where less basic constitutional liberties are in jeopardy, proof of the sufficiency of less onerous forms of regulation should be persuasive. In the field of conditioned benefits-particularly where there is doubt about government's power to act directly-perliaps the government should bear the burden of proving that no less onerous means can be found.

It might be that some other form of condition, rather than direct regulation, would be less burdensome and thus preferable. For example, a California city or county may still be able to impose narrow restrictions on the partisan pohtical activities of its civil servants if it can show that the condition is no broader than the regulable evil. ${ }^{107}$ Thus the judgment that one form of condition is unduly burdensome does not necessarily force government to choose between resort to direct regulation and terminating the program, but may simply require that the condition be rewritten in narrow terms more appropriate to the governmental interest.

103 See Dean Milk Co. v. City of Madison, 340 U.S. 349, 354-56 (1951); Schneider v. State, 308 U.S. 147, 164 (1939). On the obligation to employ the least onerous alternative where freedoms of expression and association are directly affected, see generally Wormuth \& Mirkin, The Doctrine of the Reasonable Alternative, 9 UTAB L. REv. 254, 267-93 (1964).

104 E.g., Sherbert v. Verner, 374 U.S. 398, 407 (1963); Shelton v. Tucker, 364 U.S. 479, 487-88 (1960).

105 See United Pub. Workers v. Mitchell, 330 U.S. 75, 113-14 (1947) (Black, J., dissenting); Linde, supra note 60 , at 33,37 .

106 Fort v. Civil Serv. Comm'n, 61 Cal. 2d 331, 338, 392 P.2d 385, 389, 38 Cal. Rptr. 625, 629 (1964); Kinnear v. City \& County of San Francisco, 61 Cal. 2d 341, 392 P.2d 391, 38 Cal. Rptr. 631 (1964).

107 In Fort, supra note 106, the California Supreme Court suggested the possibility of such narrower legislation: "A strong case, we think, can also be made for the view that permitting a public employee to run or campaign against his own superior has so disruptive an effect on the public service as to warrant restriction. It is, of course, possible to draw a restrictive provision narrowly in order to deal specifically with such abuses." Id. at 338 , 392 P.2d at 389, 38 Cal. Rptr. at 629. 
In any case, the theoretical availability of less onerous forms of regulation offers a useful criterion for judging any condition on a government benefit.

\section{How Important is the Benefit to the Individual Recipient?}

At the risk of rousing the ghost of the right-privilege distinction, we should consider the relative importance to the recipient of the encumbered benefit. Obviously the individual has a greater interest, and should receive more protection, in the enjoyment of a license to practice his profession than in a Christmas bonus. Whether one is a "right" and the other a "privilege" need not be considered, so long as the various forms of government benefits be roughly located on the spectrum of importance.

This question may be misleading and mischievous, lowever, unless one looks closely at the particular interest of the particular beneficiary. For example, twenty years ago social security might have been regarded as a mere gratuity (if one can overlook the substantial investment which the individual claimant has made during his years of employment). Recently, however, patterns of saving and insurance have probably changed in reliance upon the very existence of government assistance to cover emergencies and contingencies that once had to be met from private sources. The same shift will presumably occur with regard to the medical care of the elderly, as the first phase of Medicare goes into effect. Thus any court now called upon to weigh the importance of social security or unemployment compensation benefits should take account of the changes which rehance upon the very existence of such funds have brouglit about on the beneficiary's part. In addition; there may be less direct, but equally important, reliance on the part of persons obligated to support the beneficiary, which should not be higltly upset.

\section{E. Are Equivalent Benefits Available in the Private Sector?}

The importance of the benefit to the recipient is undoubtedly affected by the availability of similar opportunities from nongovernment sources. One who declines to take the loyalty oath required of faculty members at a state university can, for example, always teach at a private college. ${ }^{108}$ But this is much less true for teachers in elementary and secondary schools, where the private share of total employment is very much smaller -even if one includes the cluurch-affiliated schools, which are not a meaningful equivalent for all teachers. There are coming to be "public"

108 Keyishian v. Board of Regents, 345 F.2d 236, 239 (2d Cir. 1965). But cf. Adler v. Board of Educ., 342 U.S. 485, 492 (1952), in which the Supreme Court suggested that New York public school teachers who objected to the required loyalty oath "may work for the school system upon the reasonable terms laid down by the proper authorities of New York. If they do not choose to work on such terms, they are at liberty to retain their beliefs and associations and go elsewhere." 
or "governmental" branches of professions and occupations that were once confined almost wholly to the private sector. It is no answer to a public health doctor, for example, to say that the door of private practice is open when the door of state employment is closed by an unacceptable condition. ${ }^{109}$ Certain kinds of public liealth work are carried on only by the government, even though most pliysicians still work in the private sector of our society. As the public sector sliare of total employment grows, moreover, the availabihty of private-sector alternatives will diminish for many occupations.

The availability of nongovernmental equivalents is most relevant to a study of burgeoning welfare benefits. For some senior citizens, private medical insurance has always been readily accessible. But for othersparticularly those for whom Medicare now offers the greatest hope-the cost of premiums has always placed private insurance beyond reach. The same is true of other forms of insurance, and of private savings. Thus the mere existence of private-sector programs, and even their widespread use, does not always mean that most people enjoy meaningful alternatives to government benefits. Ironically, such alternatives are least viable for those who are most in need of the benefits offered by the public sector. Tle intensity of the dilemma facing the applicant or beneficiary undoubtedly depends very much upon the availability of private-sector alternatives. The condition slould be judged somewhat more critically when such alternatives are unavailable, even though this factor by itself is unlikely to be dispositive.

\section{F. How Does the Condition Influence the Beneficiary's Judgment?}

The psychological effect of the condition upon the beneficiary points up most vividly the difference between the typical foreign-corporation

100 For more sympathetic consideration of the dilemma facing the beneficiary or applicant who objects to conditions that may deter freedom of expression or conscience, see Sherbert v. Verner, 374 U.S. 398 (1963); Fort v. Civil Serv. Comm'n, 61 Cal. 2d 331, 392 P.2d 385, 38 Cal. Rptr. 625 (1964); Syrek v. California Unemployment Ins. Appeals Board, 54 Cal. 2d 519, 354 P.2d 625, 7 Cal. Rptr. 97 (1960). The Syrek case is particularly illustrative. Syrek, an applicant for unemployment insurance, had declined the first job offered to him, a civil service position, on the ground that he conscientiously opposed taking the loyalty oath which would accompany that position. There was no equivalent employment available to Syrek in the private sector. Thus the court leeld that he was entitled to unemployment benefits, having declined to accept suitable employment for "good cause." The court not only found a lack of rational relation between the oath requirement and the unemployment insurance program, but further concluded that by forcing unemployed persons to become reluctant signatories, the interaction of the two legislative programs actually worked at cross purposes. The court perceived the dilemma of the conscientious applicant: "The pressure put on an unemployed person to take the oath or go without benefits, perhaps when he is in desperate circumstances, may lead to the taking of the oath with reservations, or with actual falsehood." Id. at 530, 354 P.2d at 631, 7 Cal. Rptr. at 103. 
case and the case of the welfare-seeker. However onerous the cost, the corporation need only sacrifice economic interests in order to receive the benefit. Certain conditions imposed upon government employees and welfare recipients, however, exact a far different price: The requirement of a loyalty oath, or an enumeration of political affiliations, or a declaration of belief in God, directly affects liberties of conscience and expression which enjoy top constitutional priority. ${ }^{110}$ This difference should bear heavily upon the validity of the condition.

In making that assessment, moreover, the courts should take greater account than heretofore of the potential contribution of psychology. We should not assume that the individual resolves his dilemma in the same manner as the corporate officers, or even that the individual's decision is wholly rational. Analysis of the psychological impact of the condition upon an applicant migltt consider two levels of response: First, reaction to the very presence of any condition; and second, the impact of the particular condition.

The very fact that an offer of aid has strings attached to it is undoubtedly significant. The welfare seeker is in line precisely because he is poor and presumably without other means of support; he cannot be expected to view the offer of welfare, with or without conditions, in complete equanimity. It is surely naive to suppose that he approaches the possible loss or forfeiture of a benefit in the same frame of mind as do the corporate managers. We need to know a great deal more than lawyers presently do about the psychological effects of being told that because one is poor, or unemployed, or simply wants to work for the government, he must restrict his activities in ways that government does not ask self-sufficient people to do. It probably makes little difference to him whether or not government could constitutionally impose similar restrictions on nonbeneficiaries. It is enough for him that other people are not in fact so encumbered.

At the second level, law and psychology surely need to collaborate more closely to understand how a beneficiary decides whether or not to accept a particular condition. Courts have tended to assume that a welfare applicant is capable of making a reasoned choice whether the price attached to the benefit he seeks is worth paying. Is it not equally plausible, however, that even the well qualified applicant may sometimes decline the aid, even if the price seems rather low, simply because the nature of

110 Lamont v. Postmaster General, 381 U.S. 301, 307 (1965); Baggett v. Bullitt, 377 U.S. 360, 372-73 (1964); Cramp v. Board of Pub. Instruction, 368 U.S. 278, 287 (1961); Torcaso v. Watkins, 367 U.S. 488 (1961); Speiser v. Randall, 357 U.S. 513, 526 (1958); Kovach v. Maddux, 238 F. Supp. 835, 843-45 (M.D. Tenn. 1965); Danskin v. San Diego Unified School Dist., 28 Cal. 2d 536, 547-48, 171 P.2d 885, 892-93 (1946) ; cf. School Dist. of Abington Township v. Schempp, 374 U.S. 203, 288-94 (1963) (Brennan, J., concurring). 
the condition offends him? ${ }^{111}$ Is this not especially likely to be his response where the condition is directed at matters of conscience or expression; which are particularly sensitive and private interests? The law in its present state of knowledge can do no more than raise such questions. Only with the aid of psychology can it begin to answer them. But answers must surely be found before intelligent judgments are inade about the overall effect and validity of conditioned welfare benefits.

\section{G. In What Form Is the Condition Imposed?}

Any judgment about the validity of conditioned benefits should consider the form and clarity of the condition. Some conditions are fully explained to the apphicant at the time the benefit is offered, and the consequences of a breacl are made quite clear. Other conditions, however, remain largely obscure, and the withdrawal of the benefit may catch the beneficiary by surprise. Especially suspect should be conditions which are imposed after the benefit has been sought or granted. Consider, for example, the case of the political deportee's forfeiture of social security benefits which the Supreme Court recently upheld. ${ }^{112}$ The beneficiary, a Bulgarian, had entered the United States more than twenty years before enactment of the Social Security legislation. He becaune a Communist during the 1930's, when party membership was neither illegal nor a ground for deportation. For two decades he and his employer had made regular contributions to the social security program. Shortly before his retirement, Congress decreed that any person deported from the country because of past Communist party inembership (which had since been made a ground for deportation) would forfeit all social security benefits. After the man had been deported under this law his wife (who was not deported) tried unsuccessfully to obtain social security on his account. The courts agreed with the Administrator that the denial of benefits was constitutional.

This was a case in which the potential beneficiary was taken by surprise in two major respects: At the time he began contributing to the social security program, and thus made his first "application" for benefits, there was no warming that his political activities might eventually jeopardize his claim. ${ }^{113}$ Second, at the time he became a Cominumist he had no reason to fear forfeiture of his benefits. Perhaps he could not in fact have withdrawn from the social security program even if he knew of all the

\footnotetext{
111 See First Unitarian Church v. County of Los Angeles, 48 Cal. 2d 419, 446-47, 311 P.2d 508, 525 (1957) (Traynor, J., dissenting), rev'd, 357 U.S. 545 (1958) ; 112 CoNG. REc. 6 (daily ed. Jan. 10, 1966) (remarks of Representative Ryan) ; N.Y. Tines, Jan. 17, 1966, p. 46 , col. 2 ; note 39 supra.

112 Flenuming v. Nestor, 363 U.S. 603 (1960).

113 Id. at 621-22 (Black, J., dissenting).
} 
consequences; but so long as uncovered occupations were theoretically available to him, as they were during the entire period in question, even that argument is untenable.

In addition to the adequacy and timing of notice of the consequences, the specificity of the language in which the condition is stated also seems relevant. This factor has been invoked by recent Supreme Court decisions invahidating state loyalty oaths because of sweeping and uncertain provisions. ${ }^{114} \mathrm{~A}$ state may still require a loyalty oath of public employees, but "the measures which purport to define disloyalty must allow public servants to know what is and what is not disloyal."115 Whether courts will now demand the degree of specificity that would be required if the same governmental interests were effectuated through direct criminal sanctions remains for speculation. Since indirect restrictions may actually work greater mischief than direct restraints, no less strict a standard should be apphed to the language of an oath than that of a criminal law.

Finally, adequate notice requires not only an understanding that something will happen if the condition is breached, but a full appreciation of the actual consequences. Thus, one who lists his political affiliations in applying for government employment may be willing to risk not getting the job if one of his organizations is unlawful, or risk losing the job if it is later proved he has falsified his record. But he may not be willing to take the chance that the hist will be circulated around the state government, or turned over to a legislative investigating committee, for whatever reprisals may follow such wider dissemination. Similarly, under the recently invalidated postal law ${ }^{116}$ one who requested dehvery of Communist publications might have been willing to apprise the local post office of his interest in such materials. But he may have been quite unwilling to have his private employer know that he asked to receive Communist propaganda. If any such circulation of the request card had been contemplated, the power of government to impose the condition at all would be rendered much more suspect by the hidden collateral consequences of compliance. ${ }^{117}$

\section{H. What Procedures Are Provided for Determining a Breach of the Condition?}

When government moves against the individual by direct regulation, it cannot deprive him of his property or liberty without fair and formal

114 Baggett v. Bullitt, 377 U.S. 360 (1964); Cramp v. Board of Pub. Instruction, 368 U.S. 278 (1961); Wieman v. Updegraff, 344 U.S. 183 (1952).

115 Baggett v. Bullitt, supra note 114, at 380; see Morris, The University of Washington Loyalty Oath Case, 50 A.A.U.P. Burl. 221 (1964).

116 Section 305(a) of the Postal Service and Federal Employees Salary Act of 1962, 76 Stat. 840, 39 U.S.C. \& 4008(a) (1964), held unconstitutional in Lamont v. Postmaster General, 381 U.S. 301 (1965).

${ }^{117}$ Lamont v. Postmaster General, 381 U.S. 301, 307 (1965); cf. Shelton v. Tucker, 364 U.S. 479, 486-87 (1960). 
proceedings. One example will vividly illustrate the distinction. If a state university student steals a book from the campus hibrary, he has probably both violated the general criminal law and subjected himself to campus discipline. If the offense is serious enough, he may even risk loss of the "privilege" of student status. On the one hand, he cannot be jailed or fined (the direct form of regulation) without a criminal trial before an impartial judge (and perhaps a jury), the right to be represented by counsel, the privilege against self-incrimination, the right to confront his accusers, and the right of appeal. Yet for the same act, indirect regulation-even leading to the suspension or expulsion of the student, probably far more drastic in lis view than the direct sanctions of the criminal law - might be decreed following only a perfunctory administrative hearing on the campus, or possibly even without a hearing. ${ }^{118}$ And the standard justifying the impairment or withdrawal of student status might be nothing more precise than "conduct unbecoming a student" or "behavior inimical to the university"--standards which surely would never stand up in a criminal proceeding.

This contrast suggests that the procedures provided for withdrawal of the benefit are inportant in determining the validity of the withdrawal. Althougl indirect forms of regulation are seldom accompanied by the safeguards of direct criminal regulation, the protections available to the government beneficiary vary considerably. To return to the case of the state university student, for example, courts and educational adininistrators alike are requiring ever stricter procedures before expulsion or suspension can be decreed. ${ }^{119}$ Perhaps a university which guarantees every student a trial-type hearing for disciplinary proceedings should be permitted to impose more onerous conditions upon attendance than the college which retains the right to eject students summarily. Of course in practice the institution which is most equitable in its disciplinary procedures is also likely to be most enlightened in its substantive regulation of student conduct. The important point is that the sufficiency of procedures should be weighed in the balance in determining the validity of the condition. ${ }^{120}$

118 See Van Alstyne, supra note 61, at 2-6.

110 See Dixon v. Alabama State Board of Educ., 294 F.2d 150 (5th Cir.), cert. denied, 368 U.S. 930 (1961) ; Connelly v. University of Vt., 244 F. Supp. 156 (D. Vt. 1965); Knight v. State Bd. of Educ., 200 F. Supp. 174 (M.D. Tenn. 1961); Johnson, The Constitutional Rights of College Students, 42 Texas L. Rev. 344 (1964); Seavey, Dismissal of Students: "Dite Process," 70 Harv. L. Rev. 1406 (1957); Van Alstyne, Procedural Due Process and State University Students, 10 U.C.L.A.L. REv. 368 (1963); Note, Private Government on the Campus-Judicial Review of University Expulsions, 72 YaIE L.J. 1362 (1963); note 88 stipra.

120 For recent suggestions that the adequacy of procedures, and particularly the availability of a hearing, should have some bearing on the validity of conditions encumbering government benefits, see Willner v. Committee on Character and Fitness, 373 U.S. 96 (1963); 
Another relevant aspect of procedure is the allocation of the burden of proof. The United States Supreme Court struck down California's qualified property tax exemption for veterans on the rather narrow ground that the eligibility provision required the applicant to demonstrate his loyalty. ${ }^{121}$ The placement of the burden of proof, the Court held, was likely to deter a taxpayer's speecl and political activity: "The man who knows that he must bring forth proof and persuade another of the lawfulness of his conduct necessarily must steer wicler of the unlawful zone than if the State must bear these burdens." 122 The Court did not preclude California from denying tax exemptions to disloyal veterans. The state might even require veterans to file loyalty oaths as the condition of claiming the exemption-so long as the state bore the burden of proof in any contest over the validity of the declaration. The decision turned, then, on the quite narrow but important ground of burden of proof. Even where the information in issue is less sensitive than that concerning political affiliations-determination of indigency, for example-the allocation of the burden of proof may constitute a major protection to the beneficiary in case of a dispute over his qualifications.

Finally, some attention should be given to the availability of judicial review. We have observed that direct regulation is preferable to conditioning of benefits because the former can usually be challenged directly in court on its merits. But the immunity of conditioned benefits to constitutional attack is not endemic. There have been recent legislative attempts to arrange test cases and thereby circumvent the historic barriers. ${ }^{123}$ But many welfare benefit programs remain virtually immune from constitutional attack. In some programs, indeed, unreviewability is virtually ensured by explicit declarations in the statute to the effect that the administrative decision is "final." Other programs are effectively unreview-

Cafeteria \& Restaurant Workers Local 473 v. McElroy, 367 U.S. 886 (1961); Flemming v. Nestor, 363 U.S. 603, 636, 640 (1960) (Brennan, J., dissenting); Greene v. McElroy, 360 U.S. 474, 492, 496-97 (1959); Garrott v. United States, 340 F.2d 615 (Ct. Cl. 1965); Rudder v. United States, 226 F.2d 51, 53 (D.C. Cir. 1955); Heckler v. Shepard, 243 F. Supp. 841 (D. Idaho 1965); Reich, Individual Rights and Social Welfare: The Emerging Legal Issues, 74 YAIE L.J. 1245, 1252-53 (1965).

121 Speiser v. Randall, 357 U.S. 513 (1958).

122 Id. at 526. Recently the Court has extended the Speiser rationale to the motion picture censorship context. Freedman v. Maryland, 380 U.S. 51, 58 (1965), requires that "the burden of proving that the film is unprotected expression must rest on the censor."

123 Compare the rather generous judicial review provisions accompanying recent federal programs of aid for education, e.g., 72 Stat. 554 (1958), 20 U.S.C. $\S 641$ (1964); 79 Stat. 33, 20 U.S.C. $\S 241 \mathrm{k}$ (Supp. I, 1965); H.R. 4643, § 5, 81st Cong., 1st Sess. (1949), with some recent and rather restrictive provisions in federal welfare programs, e.g., the "finality" provision for certain occupational training grants, 75 Stat. 59 (1961), 42 U.S.C. $\$ 2514$ (c) (1964), and similar provisions regarding training allowances, 76 Stat. 26 (1962), 42 U.S.C. § $2583(\mathrm{~g})$ (1964). See notes 92 and 94 supra. 
able because no person has the requisite standing to protest the denial or withdrawal of the benefit, at least in the federal courts. ${ }^{124}$ Both the availability and the scope of judicial review of administrative decisions concerning government benefits should probably play a greater role than they have heretofore.

\section{CONCLUSION}

The application of these criteria will undoubtedly make more difficult many cases which now appear relatively easy. Such criteria would, for example, preclude the ready judgment that a condition is permissible because the benefit to which it is attached is a mere "privilege." These criteria would also postpone the judgment that a condition is necessarily invalid because it lacks either relevance to the benefit program, or a foundation in direct regulatory power. Suspended judgment and critical examination of all the factors are essential in these cases, however, unless we are ready to treat the welfare recipient like the foreign corporation for purposes of conditioned benefits. At some time, the courts may adopt the "entitlement" theory of welfare benefits; thus rendering less necessary the kind of analysis to which this article is directed. But until that time comes, it is probably better to escape slowly from the shackles of the old corporation and "privilege" cases than to try to make the sudden and dramatic break which "entitlement" requires. The process of emancipation must be guided through discriminating, and legally familiar, channels. The criteria suggested here are designed to ease that transition.

Even if the courts do determine that welfare benefits partake of some of the qualities of "property," the criteria outhined here may still be useful. For the property concept is not inonolithic or unidimensional; government permissibly conditions more traditional proprietary interests to an extent determined by, among other factors, the strength of its interest in the particular restriction, the relevance of that restriction to some permissible governmental objective or program, and the character of the owner's interest in the unfettered use of the property. These criteria suggest obvious and strong parallels by which to evaluate the constitutionality of conditions upon government benefits, whether or not the beneficiary's interest is viewed as proprietary.

One matter remains, and will have to wait for another day. The criteria suggested here are obviously not self-applying. There is no inherent order of priority or preference among them, no natural weiglit to be given in the balancing process. The development of general formulae to structure the balancing process will have to await further study of the particular criteria-for example, the psychological impact of certain types

124 Sẹe Unitẹd Pub. Workẹrs v. Mitchell, 330 U.S. 75, 86-91 (1947); note 92 supra. 
of conditions-and extensive field research on the nature, purpose, and use of conditions of many kinds. For the moment, about all that can safely be said is that balancing of the criteria is (1) necessary, (2) difficult, and (3) inhospitable to generalization. But even without general formulae, the balancing process should be roughly workable; there has already been some limited use of an ad hoc balancing approach to conditions. Whatever else may be said of the criteria-balancing approach to conditioned welfare and other government benefits; it is at least more flexible than what we now have. 